\title{
Panoráma ruského myšlení, kultury a vzdělání
}

\author{
Ivo Pospíšil (Brno)
}

Vozzrenija. Poučitel'nyje razmyšlenija vydajuščichsja otečestvennych dejatelej kultury, nauki i obrazovanija (XVIII-XX vv). I-II. Sostavitel' V. P. Dëmin. Moskva: Federal'noje Gosudarstvennoje bjudžetnoje naučnoje učreždenije, Institut chudožestvennogo obrazovanija i kul'turologii Rossijskoj akademii obrazovanija, 2018. I. 351 s., II. 319 s. ISBN 978-5-905451-52-2.

Přítomné dvousvazkové kompendium je svým charakterem vědecké, ale současně může sloužit aplikačním účelům, tedy jako učebnice, antologie, podkladový materiál $\mathrm{k}$ dalším výzkumům. Zásadním problémem takové publikace je výběr autorů a ukázek, jejich dostatečná reprezentativnost a hlavně rozsah myšlenkového panoramatu. Jako trochu netradiční mi připadnou dva medailony dvou žen, které stály nebo stojí v čele Ruské akademie vzdělávání (Jekatěrina Daškova, 1743-1810, Ljudmila Verbickaja, nar. 1936). Dvoudílné kompendium je sestaveno pečlivě, s rozmyslem a s vysokou mírou reprezentativnosti. Slovo „vozzrenija“ z titulu, lexikální jednotka staroslověnského původu, v ruštině tedy s vysokým stupněm abstrakce, znamená názor, pohled, dokonce přesvědčení: jde o úryvky z děl autorů, kteří byli vědci, spisovateli, mysliteli, psali různé věci, a právě zde se vyjadřovali ke kultuře a vzdělání, což primárně zajímá vydavatel a editory z Ústavu uměleckého vzdělávání a kulturologie Ruské akademie vzdělávání. Významné osobnosti, zejména starších období nešlo pominout, takže se zde vedle sebe ocitli M. Lomonosov, G. Děržavin, D. Fonvizin, I. Krylov, A. Radiščev, N. Karamzin, V. Žukovskij, tedy básníci, prozaici a dramatici představující přechod od osvícenského klasicismu k preromantismu a romantismu. Najdeme tu Lomonosoviov text o dějinách Ruska, Děržavinovy úvahy o lyrice, známé Žukovského pojednání o smrti Puškina stylizované jako dopis jeho otci Sergeji Lvoviči, jenž syna přežil o 11 let (zemřel 1848). Texty jsou různě tematicky zaměřeny, ale společným jmenovatelem je vztah ke kultuře, kulturnosti a zdělávání.
Někdy nás autoři překvapí, nebot jde často o texty stojící jakoby v pozadí jako něco marginálního, ale nakonec vidíme, že je to naopak právě jádro autorské osobnosti. Např́klad zamyšlení Sergeje Aksakova nad divadelním uměním, Puškinovy reflexe o vzdělávání lidu, projekt Ivana Turgeněva o šíření gramotnosti a základního vzdělávání. Nejde však jen o výtvory umělecké prózy nebo publicistiky; najdeme tu i báseň, třeba tu od N. Někrasova o baletu, Gogolovu úvahu o výuce obecných dějin, recenzní text na výchovné téma V. Bělinského, Ogarjovovu báseň, etické pojednání M. Saltykova-Ščedrina na téma Ctnosti a vady, oceníme stručnost A. Čechova, stejně jako štiplavou ironii D. Pisareva nebo seriózní text F. Dostojevského o literatuře a gramotnosti. V prvním dílu jsou zastoupeni autoři 19. století, ale řada důležitých osobností chybí a zdaleka tu nejsou prezentovány ani všechny podstatné metodologické proudy.

Co lze ocenit v druhém dílu, který zachycuje prolínání ruské klasiky a moderny: odvahu k samostatnosti výboru, vyzdvižení periferie, nikoli jen jádra systému, partie o jiných druzích umění, než je krásná literatura. V druhém dílu najdeme skutečná „esa“ ruského myšlení, filozofy, ale hlavně samotné spisovatele, teoretiky literatury a kultury apod. Jsou tu úvahy o duchovnosti z pera N. Berd’ajeva, čítanková reflexe Ruský charakter, jejímž autorem je „sovětský hrabě“ Alexej N. Tolstoj, mimo jiné autor románů Petr I. a Křrzzová cesta, Bachtinovo srovnání Rabelaise a Gogola, úvaha V. Vernadského o noosféře, poněkud v duchu Teilharda de Chardin, ale také studie L. Vygotského o psychologii herce, reflexe D. Lichačova Ekologie kultury a text Alexije II. (A. M. Ridiger), 
patriarchy moskevského a vší Rusi, o pravoslavném vzdělávání; $S$. Šmidt píše o tom, co by měl vědět učitel občanů 3. tisíciletí. Je to však také hořký př́spěvek o tom, kdo umírá na prahu devadesátých let minulého století, člověka, jenž stál u zrodu spisovatele Solženicyna a publikace jeho novel v časopise Novyj mir, V. Lakšina, účastníka někdejší slovenské solženicynovské konference, jenž se tu hrozí ruské společnosti, která zrovna za Jelcina začala vznikat, v níž peníze porážejí duchovnost a kde „lidem bude povoleno být zlými“ (Lakšin umírá už na jejím samém počátku roku 1993, takže už neviděl všechny kataklyzmatické peripetie jejího vývoje a nynější vyústění). ${ }^{1}$

Ve všech textech je rys predikce a varování - od 18. století, kdy šlo o „poučování moci“, po kritickou současnost. To, co je přínosné, je právě netuctovost těchto textů, resp. jejich zaměřenost na kulturu a vzdělání: $\mathrm{k}$ tomu řekli své L. Tolstoj, ale svým způsobem i V. Astafjev $o$ více než sto let později. Snad to nebude znít příliš pateticky, když napíšu, že z obou dílů této publikace vane síla ruského myšlení a ruského ducha, schopnost povznést se nad každodennost, ale také poučovat politickou moc a nepř́mo ji vést $\mathrm{k}$ sebereflexi a obezřetnosti: zed' mezi mocnými a bezmocnými je někdy opravdu tenká.

Co nás překvapí: je to především jazyk textů a jeho vývoj. Jak člověk čte současné ruské texty, musí uznat jejich značnou strukturní odlišnost od toho, co představují texty ruského 18.-20. století. Jejich soumrak jsme kdysi s J. Gazdou analyzovali ve společné knize, jež zachycovala ono přemostění od osmdesátých let po začátek 21. století - tam šlo ještě o „starou“, poetickou a stylově vícevrstevnatou ruštinu, která

1 Viz náš někdejší překlad jeho textu: LAKŠIN, V.: Solženicyn a ti druzi. Demokrat. Brno, 6. 3. 1991. se teprve začínala měnit. ${ }^{2}$ Ale podobně je tomu $\mathrm{s}$ češtinou, i když ta $\mathrm{v}$ tom má méně možností, nebot neobsahuje dva jazyky v jednom jako ruština. Nová doba přináší všude vyprázdněnost a relativní jazykovou chudobu, jazykovou unifikaci, často neuvěřitelnou uniformitu, redukci prostředků čistě jazykových a stylových, ale také chudobu lexikální - to ruštině zatím zcela nehrozí, nebot' staroslověnština jako stylistická vrstva z moderní ruštiny zcela nemizí - na rozdíl od jiných slovanských jazyků - je díky proslulé diglosii značně flexibilní.

Mohli bychom se divit, kdo v takové antologii chybí, když zaměření na kulturu a vzdělávání vyřadilo texty, které mají $\mathrm{k}$ takové tematice vztah jen zprostředkovaný: proč tam nejsou slavjanofilové a konzervativci mnohem reprezentativněji, proč tam chybí Čaadajev, neoklasicista Gončarov s jeho cenzurní praxí, ruští symbolisté, třeba Merežkovskij nebo Bělyj, ruští fenomenologové (snad s výjimkou Bachtina) a později hermeneutici. Ti všichni řekli i k tématu kultury a vzdělávání své podstatné slovo, nemluvě o sovětském období, v němž najdeme řadu vynikajících osobností, mezi něž patřil např. Lunačarskij a další představitelé originálního ruského marxismu, ale také představitelé četných uměleckých skupin dvacátých let 20. století. Chybí tu i ruská postmoderna a její tvůrci a myslitelé. Jsem přesvědčen o tom, že je to škoda, i když chápu, že kritérium reprezentativnosti a hlavně tematického zaměření je tu překážkou. Vidím tuto dvoudílnou antologii jako $\mathrm{v}$ podstatě zdařilou sondu, která čtenářům otvírá další možnosti jako svérázný průvodce textovou sítí, jenž umožňuje poznat skutečné Rusko a jeho problémy.

2 GAZDA, Jiří - POSPÍŠIL, Ivo: Proměny jazyka a literatury v současných ruských textech. Brno: Ústav slavistiky, Filozofická fakulta Masarykovy univerzity, Masarykova univerzita, 2007.

prof. PhDr. Ivo Pospíšil, DrSc.

Ústav slavistiky

Filozofická fakulta, Masarykova univerzita

Arna Nováka 1, 60200 Brno, Česká republika

ivo.pospisil@phil.muni.cz 